\title{
Surgical Treatment of Tympanic Perforations (Anatomical Results) in the Otorhinolaryngology and Cervico-Facial Surgery Department of the Peace Hospital of Ziguinchor in Southern Senegal
}

\author{
Ndadi Tchiengang K Junie* and Diom Siga Evelyne \\ Department of ENT, Peace Hospital of Ziguinchor, Senegal
}

Submission: August 11, 2020; Published: August 27, 2020

*Corresponding author: Ndadi Tchiengang K Junie, ENT Department, Peace Hospital, Ziguinchor, Senegal

\begin{abstract}
Introduction: For infants and children with severe to profound hearing impairment, cochlear implantation is the widely accepted surgery of choice. There has been a recent shift of electrode array insertion from bony cochleostomy to round window membrane (RWM) insertion. Round window membrane is strategically placed which could be accessed after an optimal post tympanotomy. St. Thomas hospital (STH) classification is used to evaluate the accessibility of RWM insertion of electrode array and can be classified as Types I, IIa, IIb and III. In type I RWM is $100 \%$ visible and insertion is straight forward while in type III RWM is not visualized at all and a bony cochleostomy is undertaken.
\end{abstract}

Material \& Methods: A total of 190 patients were included with minimum age of 1.5 years and maximum of 4.1 with mean of 2.76 , There were $48.2 \%$ males and $50.3 \%$ females in the group. Children with diagnosed syndromes or age more than 4.5 were not included in study.

Results: The cause of hearing loss in majority of cases was unknown (53.7\%) followed by low birth weight (14.7\%), maternal infections (12.6\%), meningitis (6.3\%), birth asphyxia and jaundice (5.3\%) and non-inherited congenital (2.1\%) All the type III pts underwent bony cochleostomies $(2.1 \%)$ while simple round window insertions were $65.3 \%$ (32.2\% in Type I, $54.8 \%$ in type II a and $12.9 \%$ in Type II b) and $32.6 \%$ underwent extended round window insertion. (33.8\% in type II and $66.1 \%$ in Type II b).

Conclusion: STH classification is an easy way to assess the accessibility of RWM insertion in patients planned for cochlear implantation provided that a proper posterior tympanotomy has been undertaken.

Keywords: Sensorineural hearing loss; Facial recess; CI electrode; Cochlea; Promontory cochleostomy; Round window membrane; Ear infection; Minimal perilymph loss; Acoustic trauma

\section{Letter to Editor}

Chronic or recurrent middle ear infections are associated with severe sequelae such as tympanic perforation or retraction. A tympanic perforation is simple when there is no effusion or any severity factor. This is indeed the case of traumatic perforations which have the highest rate of spontaneous closure [1]. Severity factors are chronic or multi-recurrent otorrhea, marginal perforation on the tympanic frame or the hammer manubrium, epidermosis, craniofacial malformations, ciliary dyskinesia or immune deficiencies, deafness hardly fitted [2]. Tympanic membrane perforation surgery can be referred to by two terms: myringoplasty and tympanoplasty. In the first case, it is a sole reconstruction of the tympanic membrane with or without detachment of the tympano-meatal flap and in the second case, procedures on the structures of the middle ear are associated [2].

The purpose of this surgery is to close the tympanic perforation in order to avoid superinfection [3], to improve hearing when it is affected [4], to prevent long-term hearing degradation [5], and to prevent epidermal migration into the middle ear from the perforation margins [2]. A distinction is made between the transmeatal (ductal route), endaural (Shambaugh route) and retro auricular (postero superior route) approaches. The choice is up to the surgeon depending on his preference, but also on the site of the perforation, its extent, and the external auditory meatus [2]. Fascia, particularly temporal fascia, is the 
most widely used material for tympanoplasty because it is strong, durable, easy to obtain and manage. It must be used sufficiently dry and rigid [6]. The picking of conqual or tragal cartilage has become compulsory. Collecting cartilage and perichondrium is trending now, so aponeurosis removal is less frequent than it was [7]. Many tympanoplasty techniques have been described. Despite this, failures are not uncommon. They are either due to the persistence of an inflammatory mucosal pathology, or to the technique used [8].

In the ENT and CCF department of the Peace Hospital of Ziguinchor, in the south of Senegal, we performed 20 tympanoplasty procedures between January 1 $1^{\text {st }}, 2018$ and December 31 $1^{\text {st }}, 2019$. Three of them were type 2 reinforcement tympanoplasties and the other 17 were type 1 tympanoplasties performed for tympanic perforation as a sequel of a chronic otitis media or a post-traumatic perforation. The approach was almost always shambaugh's and the majority of tympanoplasty repairs were done with a double underlay graft. No graft falls were recorded. Five cases of punctiform perforations occurred between one and two months after surgery and closed spontaneously. There were pauci symptomatic reperforations which were natural ventilators necessary to maintain middle ear ventilation and therefore not a failure of the procedure. Only one case of large perforation was recorded 6 months after tympanoplasty and required a revision surgery. Double graft tympanoplasty - temporal aponeurosis and tragal cartilage in underlay-gives excellent anatomical results. The grafts are easily removable, malleable, and strong, it is a well proven technique.

\section{References}

1. Amadasun JEO (2002) An observational study of the management of traumatic tympanic membrane perforations. J Laryngol Otol 116 (3): 181-184.

2. Updating of the 2003 SFORL AND CCF recommendation, Surgical treatment of tympanic perforations in children.

3. Bluestone CD (1998) Role of surgery for otitis media in the era of resistant bacteria. Pediatr Infect Dis J 17(11): 1090-1098.

4. Updating of the SFORL and CFC recommendation of 2003, Surgical treatment of tympanic perforations in children.

5. Rozendorn N, Wolf M, Yakirevich A, Shapira Y, Carmel E (2016) Myringoplasty in children. Int J Pediatr Otorhinolaryngol 90: 245-250.

6. Papp Z, Rezes S, Jokaay I, Sziklai I (2003) Sensorineural hearing loss in chronic otitis media. Otol Neurotol 24 (2): 141-144.

7. Thesis $N^{\circ} 131$ (2018) Study of the failure factors of tympanoplasty.

8. S Tringali (2008) Tympanic perforations and tympanic transplants. otolaryngology and cervico-facial surgery 1 (25): 261-272.

\section{Your next submission with Juniper Publishers will reach you the below assets}

- Quality Editorial service

- Swift Peer Review

- Reprints availability

- E-prints Service

- Manuscript Podcast for convenient understanding

- Global attainment for your research

- Manuscript accessibility in different formats

( Pdf, E-pub, Full Text, Audio)

- Unceasing customer service

Track the below URL for one-step submission https://juniperpublishers.com/online-submission.php 